\title{
EFEKTIVITAS NEURAL MOBILIZATION TERHADAP PENINGKATAN AKTIVITAS DAN KEMAMPUAN FUNGSIONAL PADA ISCHIALGIA
}

\author{
${ }^{1)}$ Siti Khadijah, ${ }^{2)}$ Illham Setya Budi \\ ${ }^{1,2)}$ Program Studi Fisioterapi, Fakultas Ilmu Kesehatan, Universitas Muhammadiyah Surakarta \\ Jl. A. Yani Tromol Pos I Pabelan Kartasura Telp. (0271) 717417 Fax. (0271) 715448 Surakarta \\ 57162
}

Email : stkhdi3@gmail.com

\begin{abstract}
ABSTRAK
Tujuan: Mengidentifikasi efektivitas neural mobilization terhadap peningkatan kemampuan fungsional pada pasien ischialgia et causa compression fractures.

Metode: Metode penelitian meliputi studi kasus "case report” yang dilakukan pada 2 orang pria dengan kondisi ischialgia et causa compression fractures. Alat ukur yang digunakan seperti VAS untuk derajat nyeri, pita ukur untuk ROM trunk, SLR test untuk pemeriksaan sensitivitas jaringan neurologis terhadap tekanan mekanis, MMT untuk kekuatan otot, dan modified oswestry low back pain disability questionnaire untuk kemampuan fungsional. Intervensi fisioterapi dengan neural mobilization. Evaluasi diukur setelah 2 kali perlakuan dengan menggunakan alat ukur yang sama. Outcome yang digunakan adalah modified oswestry low back pain disability questionnaire untuk mengukur kemampuan fungsional pasien.

Hasil: Setelah dilakukannya terapi sebanyak 2 kali didapatkan hasil penilaian pada pasien 1 dan 2 ialah adanya perubahan pada derajat nyeri, ROM trunk, namun belum adanya perubahan pada kekuatan otot.

Kesimpulan: Adanya perubahan terhadap derajat nyeri dan ROM trunk, namun belum adanya perubahan pada kekuatan otot yang menunjang peningkatan aktivitas dan kemampuan fungsional pasien. Merujuk pada hasil penelitian, perlu dilakukannya penelitian dengan waktu yang cukup lama untuk menyelesaikan permasalahan pada ischialgia et causa compression fractures.
\end{abstract}

Kata kunci: Ischialgia, Low back pain, Neural mobilization.

\section{ABSTRACT}

Objective: To identify the effectiveness of neural mobilization on improving functional abilities in patients with ischialgia et causa compression fractures.

Method: The research method includes case studies of "case reports" conducted on 2 men with conditions of ischialgia et causa compression fractures. Measuring instruments used such as VAS for the degree of pain, measuring tape for trunk ROM, SLR test for examination of neurological tissue sensitivity to mechanical stress, MMT for muscle strength, and modified oswestry low back pain disability questionnaire for functional abilities. Physiotherapy intervention with neural mobilization. Evaluation was measured after 2 treatments using the same measuring instrument. The outcome used was a modified oswestry low back pain disability questionnaire to measure patients functional abilities.

Results: After doing the therapy twice, the results of the assessment in patients 1 and 2 showed that there was a change in the degree of pain, trunk ROM, but there was no change in muscle strength.

Conclusion: There is a change in the degree of pain and trunk ROM, but there has been no change in muscle strength that supports increased activity and functional ability of patients. Referring to the results of the study, it is necessary to conduct a study with a long enough time to solve the problems in Ischialgia et Causa compression fractures.

Keywords: Ischialgia, Low back pain, Neural mobilization. 


\section{PENDAHULUAN}

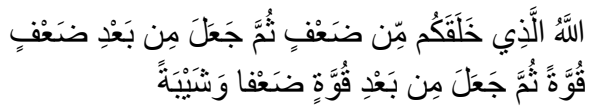

"Allah-lah yang Menciptakan kamu dari keadaan lemah, kemudian Dia Menjadikan (kamu) setelah keadaan lemah itu menjadi kuat, kemudian Dia Menjadikan (kamu) setelah kuat itu lemah (kembali) dan beruban." (Q.S ar-Rum: 54). Al-quran bertutur, manusia melewati 3 masa dalam hidupnya. Satu masa kekuatan yang diapit oleh 2 masa kelemahan. Masa kekuatan itu adalah masa remaja yang diapit oleh masa kecil dan masa tua yang penuh kelemahan. Masa tua merupakan fase terakhir yang akan dilalui oleh manusia dimana akan menurunnya semua fungsi tubuh, sehingga berbagai macam penyakit akan menyerang tubuh lansia (lanjut usia). Lansia adalah seseorang yang telah mencapai umur 60 tahun ke atas (Azizah, 2011).

Ischialgia merupakan salah satu manifestasi dari nyeri punggung bawah yang dikarenakan adanya penjepitan nervus ischiadicus. Nyeri yang dirasakan adalah nyeri menjalar kebawah sepanjang perjalanan akar saraf ischiadicus. Ischialgia itu sendiri adalah sebuah gejala dimana pasien akan merasakan nyeri pada tungkai yang menjalar dari akar saraf kearah distal perjalanan nervus ischiadicus sampai ke tungkai bawah (Calliet, 2010).

Gangguan ini sering terjadi akibat dari posisi yang salah saat beraktifitas (Pratiwi et al., 2009). Pravelensi terjadinya low back pain di dunia mencapai 9,17\%. Episode satu tahunan terjadinya episode pertama low back pain ini mencapai $24 \%$ sampai $80 \%$. Keterulangan terjadinya low back pain ini sangat tinggi sehingga perlu perhatian (Hoy et al., 2010). Angka kejadian menurut survei yang dilakukan oleh America Osteopathic Association (AOA) pada tahun 2013 menunjukkan bahwa dari 1.000 pekerja kantor berumur 18 tahun ke atas di Amerika Serikat, 2 dari 3 pekerja kantor mengalami nyeri di daerah tubuhnya pada 6 bulan terakhir. Dalam survei tersebut menunjukkan dalam 30 hari terakhir sekitar $62 \%$ responden merasakan nyeri di punggung bawah, $53 \%$ di leher, $38 \%$ di bahu, $33 \%$ di pergelangan tangan, dan $31 \%$ di punggung bagian atas (Putri, Mulyadi, dan Lolong, 2014).

Di Indonesia menurut penelitian yang dilakukan oleh Perhimpunan Dokter Spesialis Saraf Indonesia (PERDOSSI) pada bulan Mei 2002 dikatakan bahwa jumlah penderita nyeri sebanyak 4.456 orang $(25 \%$ dari total kunjungan rumah sakit) dimana 819 orang $(18,37 \%)$ adalah low back pain (Nugroho, 2012). Di Sulawesi Utara khususnya kota Bitung, menurut observasi peneliti di Rumah Sakit Umum Daerah (RSUD) Bitung, pada bulan November 2016 sampai Januari 2017, jumlah kunjungan pasien di polikilinik fisioterapi sekitar 200 pasien per bulannya. Kunjungan untuk pasien low back pain sendiri berkisar 30 pasien pria, dan 24 pasien wanita, dengan jumlah kunjungan setiap pasien per minggu sekitar 2-3 kali.

Intervensi medis yang sering digunakan adalah terapi farmakologi dengan pemberian medika mentosa untuk mengurangi nyeri punggung bawah yaitu golongan OAINS, opiod, analgesik non opioid, antikonvulsan, antidepresan, dan muscle relaxant (relaksan otot) (Piccoliori et al., 2013). Terapi nonfarmakologi yang disarankan adalah mobilisasi saraf atau neural mobilization.

Neural mobilization merupakan teknik untuk mengurangi rasa sakit karena gangguan pada saraf. Teknik ini digunakan untuk meningkatkan mobilitas nervus ischiadicus, mengurangi mekanosensitivitas sistem saraf, meningkatkan kerja saraf, dan mengurangi nyeri punggung bawah. Melalui teknik ini kerusakan pada saraf akan berkurang, nyeri berkurang, Range of Motion (ROM) meningkat, kemampuan beradaptasi dinamis dari sistem saraf meningkat sehingga dapat meningkatkan kemampuan fungsional pasien. 
Berdasarkan dengan penelitian yang dilaukan di rumah sakit $J$ oriental medicine Korea terhadap individu dengan low back pain yang berusia diantara 30-50 tahun yang menggunakan alat ukur berupa Oswestry Disability Index (ODI) dengan intervensi fisioterapi yaitu neural mobilization yang terdiri dari Straight Leg Raise (SLR) adalah adanya reaksi penyembuhan saraf dan pengurangan nyeri punggung bawah (Ui et al., 2016).

Berdasarkan studi pendahuluan didapatkan informasi bahwa neural mobilization sudah dilakukan namun belum optimal. Tidak semua pasien mengikuti anjuran latihan karena pasien didominasi oleh lansia yang kurang aktif dalam memanfaatkan pelayanan kesehatan. Belum ada leaflet yang dapat memperjelas informasi neural mobilization. Oleh karena itu pasien datang dan periksa kembali dengan keluhan yang sama yaitu nyeri punggung bawah. Sehingga, penelitian ini bertujuan mengidentifikasi efektivitas neural mobilization terhadap peningkatan aktivitas dan kemampuan fungsional tanpa ada rasa nyeri pada penderita ischialgia.

\section{METODE}

Studi ini menggunakan pendekatan studi kasus dengan case report yang dilaksanakan pada 2 pasien laki-laki dengan diagnosis ischialgia et causa comression fractures.

\section{Pemeriksaan Subjektif}

Pasien dengan jenis kelamin laki-laki yang berumur 67 tahun dan 40 tahun dengan keluhan utama nyeri menjalar dari pinggang ke kaki kanan dan kaki kiri. Faktor yang memperberat nyeri adalah ketika pasien sedang beraktivitas misalnya berjalan, aktivitas mengangkat, dan bepergian. Sedangkan yang membuat ringan keluhan adalah ketida beristirahat, berbaring, atau duduk.

Oleh karena adanya keluhan tersebut pasien datang ke rumah sakit untuk memperoleh tindakan medis. Dokter mendiagnosa pasien mengalami ischialgia. Pasien mendapatkan terapi farmakologi berupa obat-obatan dan terapi non-farmakologi yang dirujuk ke fisioterapi untuk mendapatkan penatalaksanaan fisioterapi. Tujuan dari penatalaksanaan fisioterapi untuk meningkatkan aktivitas dan kemampuan fungsional yang dapat menunjang aktivitas sehari-hari atau meningkatkan kualitas hidup pasien.

\section{Pemeriksaan Fisik}

Pemeriksaan fisik dilakukan dengan metode tertentu dan secara berurutan. Pemeriksaan fisik menggunakan alat ukur berupa VAS (Visual Analog Scale) untuk derajat nyeri yang dapat dilihat pada Tabel 1 dan 2, kekuatan otot dengan MMT (Manual Muscle Testing) yang dapat dilihat pada Tabel 3, dan ROM trunk dengan pita ukur yang dapat dilihat pada Tabel 4. Tes khusus dengan segmental test, quick test, spurling test, valsava maneuver, dan SLR test yang dapat dilihat pada Tabel 6. Validitas dan reabilitas alat ukur dapat dilihat pada Tabel 7. Hasil pemeriksaan dengan menggunakan alat ukur diatas adalah adanya nyeri punggung bawah, penurunan kekuatan otot fleksor trunk, dan penurunan ROM trunk yaitu fleksi trunk. Segmental test, quick test, spurling test, valsava maneuver, dan SLR test menunjukkan adanya peningkatan nyeri punggung bawah.

Tabel 1. Persepsi nyeri pasien 1

\begin{tabular}{cccc}
\hline Jenis nyeri & $\begin{array}{c}\text { M. } \\
\text { Erectore } \\
\text { spine }\end{array}$ & $\begin{array}{c}\text { Proc } \\
\text { spinosus V1 }\end{array}$ & $\begin{array}{c}\text { Nyeri } \\
\text { Menjalar }\end{array}$ \\
\hline Nyeri diam & $0 \mathrm{~cm}$ & $0 \mathrm{~cm}$ & $3,2 \mathrm{~cm}$ \\
Nyeri tekan & $2,8 \mathrm{~cm}$ & $4,8 \mathrm{~cm}$ & $5,2 \mathrm{~cm}$
\end{tabular}




Nyeri gerak $\quad 4,7 \mathrm{~cm} \quad 5,2 \mathrm{~cm} \quad 7,3 \mathrm{~cm}$

Tabel 2. Persepsi nyeri pasien 2

\begin{tabular}{cccc}
\hline Jenis nyeri & $\begin{array}{c}\text { M. } \\
\text { Erectore } \\
\text { spine }\end{array}$ & $\begin{array}{c}\text { Proc } \\
\text { spinosus } \mathrm{Vl}\end{array}$ & $\begin{array}{c}\text { Nyeri } \\
\text { Menjalar }\end{array}$ \\
\hline Nyeri diam & $1,8 \mathrm{~cm}$ & $2,3 \mathrm{~cm}$ & $3,6 \mathrm{~cm}$ \\
Nyeri & $2,4 \mathrm{~cm}$ & $4,7 \mathrm{~cm}$ & $4,5 \mathrm{~cm}$ \\
tekan & & & \\
Nyeri & $4,9 \mathrm{~cm}$ & $6,5 \mathrm{~cm}$ & $6,6 \mathrm{~cm}$ \\
gerak & & & \\
\hline
\end{tabular}

Hasil pemeriksaan nyeri dengan menggunakan VAS

Tabel 3. Kekuatan otot

\begin{tabular}{ccc}
\hline $\begin{array}{c}\text { Kelompok } \\
\text { otot }\end{array}$ & Pasien 1 & Pasien 2 \\
\hline Fleksor & 4 & 4 \\
Ekstensor & 5 & 5 \\
\hline
\end{tabular}

Hasil pemeriksaan kekuatan otot dengan MMT

Tabel 4. ROM trunk pasien 1

\begin{tabular}{cc}
\hline Gerakan & Nilai \\
\hline Fleksi & $45-41 \mathrm{~cm}=4 \mathrm{~cm}$ \\
Ekstensi & $41-39,5 \mathrm{~cm}=1,5 \mathrm{~cm}$ \\
Side fleksi kanan & $47-32 \mathrm{~cm}=15 \mathrm{~cm}$ \\
Side fleksi kiri & $47-30 \mathrm{~cm}=17 \mathrm{~cm}$ \\
\hline
\end{tabular}

Tabel 5. ROM trunk pasien 2

\begin{tabular}{cc}
\hline Gerakan & Nilai \\
\hline Fleksi & $44-40 \mathrm{~cm}=4 \mathrm{~cm}$ \\
Ekstensi & $41,5-40 \mathrm{~cm}=1,5 \mathrm{~cm}$ \\
Side fleksi kanan & $45-29 \mathrm{~cm}=16 \mathrm{~cm}$ \\
Side fleksi kiri & $45-29,9 \mathrm{~cm}=15.1 \mathrm{~cm}$ \\
\hline
\end{tabular}

Hasil pemeriksaan ROM trunk dengan pita ukur

Tabel 6. Tes khusus 


\begin{tabular}{ccc}
\hline Nama tes & Pasien 1 & Pasien 2 \\
\hline $\begin{array}{c}\text { Segmental test } \\
\text { (Hebert } \text { et al., 2013) }\end{array}$ & Positif & Positif \\
Quick test & Positif & Positif \\
Spurling test & Positif & Positif \\
Valsava manuever & Positif & Positif \\
SLR (Boyd et al., & & Positif \\
2009) & Positif & \\
\hline
\end{tabular}

Tes khusus pada ischialgia

Tabel 7. Realibility dan validity test

\begin{tabular}{lcc}
\hline Nama tes & validity & realibility \\
\hline VAS (G. A & $0,71-$ & 0,71 \\
Hawker et al., & 0,78 & \\
2011) & & 0,95 \\
ROM pita ukur & - & \\
(Zaobi, 2012) & & 0,89 \\
$\quad$ MMT & & \\
$\quad$ Raymond et & 0,79 & \\
$\quad$ al., 2006). & & $0,59-0,73$ \\
Segmental test & & \\
(Hebert et al., & - & - \\
2013 & & \\
Quick test & - & \\
Spurling test & & \\
Valsava \\
manuver \\
SLR test \\
Modified
\end{tabular}

Validitas dan reabilitas alat ukur

\section{Evaluasi dan Diagnosis Fisioterapi}

Penegakan diagnosa fisioterapi berdasarkan ICF (International Classification of Function and Disability). Dalam penegakan diagnosa ditunjang oleh hasil pemeriksaan fisik yang telah dilakukan seperti pemeriksaan nyeri, pemeriksaan kekuatan otot, dan pemeriksaan ROM trunk. Tes khusus dengan segmental test, quick test, spurling test, valsava maneuver, dan SLR test. Berdasarkan hasil pemeriksaan fisik didapatkan diagnosis fisioterapi berupa impairment yaitu adanya 
nyeri menjalar dari pinggang ke kedua tungkai kanan dan kiri, penurunan kekuatan otot fleksor trunk, penurunan ROM fleksi trunk. Functional Limitation yaitu adanya keterbatasan dalam berjalan, aktivitas mengangkat, berdiri dengan waktu yang lama, dan bepergian atau melakukan perjalanan yang jauh. Disability yaitu adanya keterbatasan dalam kehidupan sosial. Hal ini didukung oleh profesi lain seperti dokter umum.

\section{Intervensi}

\section{Infrared}

Dilakukan 3x seminggu selama waktu 5-20 menit, dengan temperatur $42^{\circ}$ celcius (Ervolino \& ronald, 2016).

2. TENS (Transcutaneous Electrical Nerve Stimulation)

Dilakukan 2x/minggu, dengan frekuensi $100 \mathrm{~Hz}$, pulse width: 200 us, selama 30 menit (Bertalanffy et al., 2005).

3. Neural Mobilization

Dilakukan Passive straight leg raise dengan posisi ankle dorsi fleksi, ditahan 30 detik dengan 10x pengulangan, dilakukan 3x per hari (Petersen \& Daphne, 2010). Dapat dilihat pada Gambar 1.
Modified oswestry low back pain disability questionnaire merupakan alat ukur yang digunakan untuk mengukur aktivitas dan kemampuan fungsional penderita low back pain seperti ischialgia. Alat ukur ini mengevaluasi nyeri, tingkat kesulitan, dan kemandirian penderita atau mengukur penurunan toleransi aktivitas yang dilakukan seperti aktivitas mengangkat, berjalan, duduk, berdiri, tidur, aktivitas seksual, kehidupan sosial, dan bepergian.

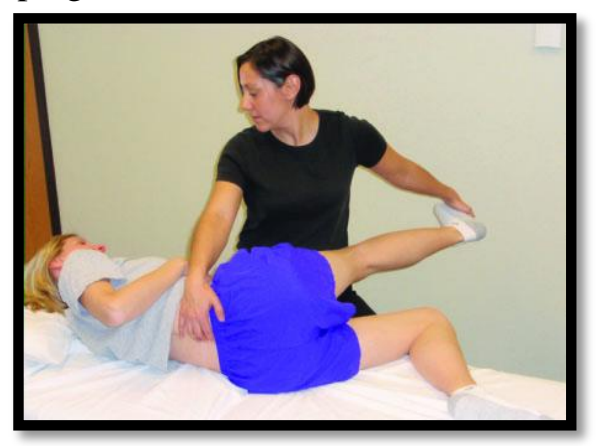

Gambar 1. Neural mobilization

(Petersen \& Daphne, 2010)

Passive straight leg raise dengan posisi angkle dorsi fleksi

\section{Outcomes}

\section{HASIL}

Tabel 8. Nyeri dengan VAS pasien 1

\begin{tabular}{|c|c|c|c|}
\hline \multicolumn{4}{|c|}{$\mathrm{T} 1$} \\
\hline Jenis & M. & Proc & Nyeri \\
\hline nyeri & $\begin{array}{c}\text { Erectore } \\
\text { spine }\end{array}$ & $\begin{array}{c}\text { spinosus } \\
\text { V13-4 }\end{array}$ & Menjalar \\
\hline $\begin{array}{l}\text { Nyeri } \\
\text { diam }\end{array}$ & $0 \mathrm{~cm}$ & $0 \mathrm{~cm}$ & $3,2 \mathrm{~cm}$ \\
\hline $\begin{array}{l}\text { Nyeri } \\
\text { tekan }\end{array}$ & $2,8 \mathrm{~cm}$ & $4,8 \mathrm{~cm}$ & $5,2 \mathrm{~cm}$ \\
\hline $\begin{array}{l}\text { Nyeri } \\
\text { gerak }\end{array}$ & $4,7 \mathrm{~cm}$ & $5,2 \mathrm{~cm}$ & $7,3 \mathrm{~cm}$ \\
\hline \multicolumn{4}{|c|}{$\mathrm{T} 2$} \\
\hline $\begin{array}{l}\text { Jenis } \\
\text { nyeri }\end{array}$ & $\begin{array}{c}\text { M. } \\
\text { Erectore } \\
\text { spine }\end{array}$ & $\begin{array}{c}\text { Proc } \\
\text { spinosus } \\
\text { V13-4 }\end{array}$ & $\begin{array}{c}\text { Nyeri } \\
\text { Menjalar }\end{array}$ \\
\hline $\begin{array}{l}\text { Nyeri } \\
\text { diam }\end{array}$ & $0 \mathrm{~cm}$ & $0 \mathrm{~cm}$ & $2,9 \mathrm{~cm}$ \\
\hline Nyeri & $2,6 \mathrm{~cm}$ & $4,6 \mathrm{~cm}$ & $4,8 \mathrm{~cm}$ \\
\hline
\end{tabular}


tekan

Nyeri $\quad 3,9 \mathrm{~cm} \quad 4,7 \mathrm{~cm} \quad 5,8 \mathrm{~cm}$

gerak

Tabel 9. Nyeri dengan VAS pasien 2

\begin{tabular}{|c|c|c|c|}
\hline \multicolumn{4}{|c|}{$\mathrm{T} 1$} \\
\hline Jenis & M. & Proc & Nyeri \\
\hline nyeri & $\begin{array}{c}\text { Erectore } \\
\text { spine }\end{array}$ & $\begin{array}{c}\text { spinosus } \\
\text { V13-4 }\end{array}$ & Menjalar \\
\hline $\begin{array}{l}\text { Nyeri } \\
\text { diam }\end{array}$ & $1,8 \mathrm{~cm}$ & $2,3 \mathrm{~cm}$ & $3,6 \mathrm{~cm}$ \\
\hline $\begin{array}{l}\text { Nyeri } \\
\text { tekan }\end{array}$ & $2,4 \mathrm{~cm}$ & $4,7 \mathrm{~cm}$ & $4,5 \mathrm{~cm}$ \\
\hline $\begin{array}{l}\text { Nyeri } \\
\text { gerak }\end{array}$ & $4,9 \mathrm{~cm}$ & $6,5 \mathrm{~cm}$ & $6,6 \mathrm{~cm}$ \\
\hline \multicolumn{4}{|c|}{$\mathrm{T} 2$} \\
\hline Jenis & M. & Proc & Nyeri \\
\hline nyeri & $\begin{array}{c}\text { Erectore } \\
\text { spine }\end{array}$ & $\begin{array}{c}\text { spinosus } \\
\text { V13-4 }\end{array}$ & Menjalar \\
\hline $\begin{array}{l}\text { Nyeri } \\
\text { diam }\end{array}$ & $1,5 \mathrm{~cm}$ & $2,0 \mathrm{~cm}$ & $3,3 \mathrm{~cm}$ \\
\hline $\begin{array}{l}\text { Nyeri } \\
\text { tekan }\end{array}$ & $2,1 \mathrm{~cm}$ & $4,4 \mathrm{~cm}$ & $4,2 \mathrm{~cm}$ \\
\hline $\begin{array}{l}\text { Nyeri } \\
\text { gerak }\end{array}$ & $3,8 \mathrm{~cm}$ & $5,7 \mathrm{~cm}$ & $5,9 \mathrm{~cm}$ \\
\hline
\end{tabular}

Berdasarkan pada tabel diatas, adanya penurunan nyeri dengan VAS pada pasien 1 dan pasien 2.

Tabel 10. Kekuatan otot dengan MMT

\begin{tabular}{ccccc}
\hline $\begin{array}{c}\text { Kelom } \\
\text { pok } \\
\text { otot }\end{array}$ & Pasien 1 & \multicolumn{2}{c}{ Pasien 2 } \\
\hline & T1 & T2 & T1 & T2 \\
\hline Fleksor & 4 & 4 & 4 & 4 \\
Ekstens & 5 & 5 & 5 & 5 \\
or & & & & \\
\hline
\end{tabular}

Berdasarkan pada tabel diatas, belum adanya peninkatan kekuatan otot dengan MMT pada pasien 1 dan pasien 2.

Tabel 11. ROM dengan pita ukur pasien 1

\begin{tabular}{cc}
\hline & T1 \\
\hline Gerakan & Nilai \\
\hline Fleksi & $45-41 \mathrm{~cm}=4 \mathrm{~cm}$ \\
Ekstensi & $41-39,5 \mathrm{~cm}=1,5 \mathrm{~cm}$
\end{tabular}




\begin{tabular}{cc}
$\begin{array}{c}\text { Side fleksi kanan } \\
\text { Side fleksi kiri }\end{array}$ & $47-32 \mathrm{~cm}=15 \mathrm{~cm}$ \\
& $47-30 \mathrm{~cm}=17 \mathrm{~cm}$ \\
\hline Terakan & Nilai \\
\hline Fleksi & $45-42 \mathrm{~cm}=3 \mathrm{~cm}$ \\
Ekstensi & $41-39,5 \mathrm{~cm}=1,5 \mathrm{~cm}$ \\
Side fleksi kanan & $47-32 \mathrm{~cm}=15 \mathrm{~cm}$ \\
Side fleksi kiri & $47-30 \mathrm{~cm}=17 \mathrm{~cm}$ \\
\hline
\end{tabular}

Tabel 11. ROM dengan pita ukur pasien 2

$\mathrm{T} 1$

\begin{tabular}{|c|c|}
\hline Gerakan & Nilai \\
\hline Fleksi & $44-40 \mathrm{~cm}=4 \mathrm{~cm}$ \\
\hline Ekstensi & $41,5-40 \mathrm{~cm}=1,5 \mathrm{~cm}$ \\
\hline Side fleksi kanan & $45-29 \mathrm{~cm}=16 \mathrm{~cm}$ \\
\hline Side fleksi kiri & $\begin{array}{c}45-29,9 \mathrm{~cm}=15.1 \\
\mathrm{~cm}\end{array}$ \\
\hline \multicolumn{2}{|c|}{$\mathrm{T} 2$} \\
\hline Gerakan & Nilai \\
\hline Fleksi & $44-41 \mathrm{~cm}=3 \mathrm{~cm}$ \\
\hline Ekstensi & $41,5-40 \mathrm{~cm}=1,5 \mathrm{~cm}$ \\
\hline Side fleksi kanan & $45-29 \mathrm{~cm}=16 \mathrm{~cm}$ \\
\hline Side fleksi kiri & $\begin{array}{c}45-29,9 \mathrm{~cm}=15.1 \\
\mathrm{~cm}\end{array}$ \\
\hline
\end{tabular}

Berdasarkan pada tabel diatas, adanya peningkatan ROM trunk dengan pita ukur pada pasien 1 dan pasien 2 .

\section{PEMBAHASAN}

Nyeri pada punggung bawah berasal dari proses degeneratif sendi dimana terdapat perubahan struktur tulang dan ligamen yang bisa membuat lesi pada nervus ischiadicus, mekanisme nyeri pada nervus ischiadicus ialah nyeri yang menjalar ke seluruh ekstremitas bawah sesuai jalur pendistribusian nervus ischiadicus, parethesia, rasa nyeri yang menusuk, keterbatasan gerak dan penurunan reflek. Hal ini membuat adanya keterbatasan saat melakukan aktivitas fungsional seperti berjalan, duduk, gerakan merukuk ataupun menjalankan hobi dan olahraga (Ui et al., 2016).

Penelitian ini dilakukan untuk menentukan apakah intervensi tambahan berupa neural mobilization untuk nervus ishiadicus dapat memberikan efek positif yaitu perbaikan dari saraf yang cedera dan mengurangi nyeri punggung bawah akibat cedera saraf. Hasil penelitian menunjukkan bahwa indikator kesehatan seperti fungsi fisik, 
kondisi kesehatan umum dan mental sangat mempengaruhi hasil akhir dari individu dengan ischialgia yang diberikan intervensi neural mobilization. Intervensi medis yang digunakan adalah terfokus pada neural mobilization. Intervensi dilaksanakan dengan dosis 30 detik dengan $10 x$ pengulangan yang dilakukan sebanyak 3x per hari.

Neural mobilization dapat mengurangi transmisi nyeri akibat peradangan pada jaringan saraf. Kemudian, mampu meningkatkan adaptasi saraf perifer akibat cedera saraf dan menurunkan tekanan pada saraf. Peningkatan kemampuan adaptasi saraf tepi menyebabkan penurunan reaksi hipoksia oleh edema di dalam saraf dan mengurangi kompresi pada jaringan saraf sehingga nyeri berkurang.

Setelah dilakukan terapi sebanyak 2 kali kepada pasien 1 dan 2 dengan perlakuan neural mobilization menunjukkan adanya penurunan nyeri dan peningkatan ROM trunk, namun belum adanya perubahan kekuatan otot. Kondisi diatas disebabkan karena kurangnya dosis latihan yang hanya dilakukan 2 kali perlakuan yaitu 1 minggu sekali dalam 2 minggu. Hal tersebut menyebabkan belum adanya adaptasi neurological atau saraf tepi di dalam tubuh. Terbentuknya adaptasi neurological didalam tubuh ketika latihan rutin selama 2-3 minggu.

Tidak adanya adaptasi neurological menyebabkan tidak adanya peningkatan koordinasi intra-muscular yang menyebabkan perubahan fisiologis pada penderita low back pain. Hasil ini konsisten dengan hasil penelitian oleh Cleland (2006) bahwa pasien low back pain yang diberikan intervensi berupa neural mobilization menunjukkan hasil positif dalam ODI (Cha dan Cho, 2014).

\section{KESIMPULAN DAN SARAN}

Intervensi fisioterapi berupa neural mobilization kepada pasien low back pain yaitu ischialgia yang dilakukan sebanyak 2 kali terapi adanya menunjukkan perubahan pada persepsi nyeri dan ROM trunk namun belum adanya perubahan pada kekuatan otot. Berdasarkan hasil penelitian, belum adanya perubahan terhadap peningkatan kekuatan otot yang menunjuang peningkatan aktivitas dan kemampuan fungsional pasien.

Diharapkan penelitian ini dapat dilanjutkan sehingga mendapatkan hasil yang lebih efektif dari sebelumnya.

\section{UCAPAN TERIMA KASIH}

Peneliti menyadari tanpa bantuan dan dukungan dari berbagai pihak penyusunan penelitian ini tidak dapat berjalan baik. Dalam hal ini peneliti telah banyak menerima bantuan dan bimbingan moril dan materiil. Maka tim peneliti mengucapkan terimakasih kepada dosen yang telah berkenan membagi ilmu dan pengalaman, seluruh staff rumah sakit yang telah membantu dalam sarana dan prasarana penelitian, serta pasien rawat jalan instalasi rehabilitasi medik di rumah sakit yang sudah berkenan menjadi responden dalam penelitian. Tidak lupa ucapan terimakasih kepada Universitas Muhammadiyah Surakarta Fakultas Ilmu Kesehatan Prodi Fisioterapi yang telah memberikan izin dan pendanaan terkait kegiatan penelitian ini.

\section{DAFTAR PUSTAKA}

Azizah, L, "Keperawatan Lanjut Usia". Yogyakarta: Graha Ilmu. h. 35, 2011.

Boyd, B. S., Wanek, Linda., Gray, T.Andrew., and Topp, S.Kimberly. (2009) 'Mechanosensitivity of the Lower Extremity Nervous System During Straight-Leg Raise Neurodynamic Testing in Healthy Individuals', (November). doi: 10.2519/jospt.2009.3002.

Calliet, Rene, Low Back Pain Syndrome; Second Edition, F.A. Davis Company, Philadelphia, 2010.

Cha HK, Cho HS, Choi JD: Effects of the nerve mobilization technique on lower limb function in patients with poststroke hemiparesis. J Phys Ther Sci, 2014, 26: 981-983. [Medline] 
[CrossRef]

Chhabra, H. S., Nishant, Kapoor, S.K. (2015) 'New Modified English and Hindi Oswestry Disability Index in Low Back Pain Patients Treated Conservatively in Indian Population', (January). doi:10.4184/asj.2014.8.5.632.

Ervolino, F., \& Gazze, R. (2016). Far infrared wavelength treatment for lowback pain:

Evaluation of a non-invasive device. Work, 53(1), 157-162. https://doi.org/10.3233/WOR 152152.

Hawker, S. Mian, T. Kendzerska, and M. French, "Measures of adult pain: Visual Analog Scale for Pain (VAS Pain), Numeric Rating Scale for Pain (NRS Pain), McGill Pain Questionnaire (MPQ), Short-Form McGill Pain Questionnaire (SF $M P Q)$, Chronic Pain Grade Scale (CPGS), Short Form-36 Bodily Pain Scale (SF," Arthritis Care Res., vol. 63, no. SUPPL. 11, pp. 240-252, 2011.

Hoy, D., Brooks, P., Blyth, F., and Buchbinder, R. (2010). Best Practice \& Research Clinial Rheumatology The Epidemiology of Low Back Pain. Best Practice \& Research Clinial Rheumatology, 24 (60), 769-781.

Nugroho, F. Pengaruh penambahan mobilisasi saraf dan static stretching setelah intervensi short wave diathermy untuk mengurangi nyeri akibat ischialgia. Universitas Muhammadiah Surakarta. Solo. 2012; 1-8.

Petersen, S. M. and Scott, D. R. (2010). 'Application of a classification system and description of a combined manual therapy intervention: a case with low back related leg pain', pp. 89-96. doi:

\subsection{9/106698110X1264074071} 572.

Piccoliori, G., Engl, A., Gatterer, D., Sessa, E., Schmitten, J. Der, and Abholz, H. (2013). Management of Low Back Pain in Genera Practice - Is it of acceptable quality : an observational study among 25 general practicein South Tyrol (Italy) . BMC Family Practice, 14 (148), 1471-2296.

Pratiwi MH, Setyaningsih Y, Kurniawan B, Martini. Beberapa faktor yang berpengaruh terhadap keluhan nyeri punggung bawah pada penjual jamu gendong. Journal Promosi Kesehatan Indonesian. 2009;4: 61-7.

Putri FKS, Mulyadi, Lolong J. Pengaruh pendidikan kesehatan tentang low back pain terhadap tingkat pengetahuan pegawai negeri sipil di kantor balai pelestarian nilai budaya manado. Program Studi Ilmu Keperawatan Fakultas Kedokteran Universitas Sam Ratulangi Manado. 2014.

Raymond C. , PhD, Jan M. Jasiewicz, PhD, James Middleton, $\mathrm{PhD}, \quad$ Peter Condie, BEngTech and Be. Andrew Barriskill, MBA, Heidi Hebnes, PT, Brendan Purcell, "The Development, Validity, and Reliability of a Manual Muscle Testing Device With Integrated Limb Position Sensors," Arch Phys Med Rehabil, Vol 87, March 2006, vol. 87, 2006.

Ui, C., Cheol, YK., Young, HP., Gak, HB., and Chan, WN. (2016) 'The effects of self-mobilization techniques for the sciatic nerves on physical functions and health of low back painpatients with lower limb radiating pain', the journal of physical therapy science, pp. 46-50. 